\title{
Expression of PCNA, MMP-9, p53, Bax and Bcl-2 in canine transmissible venereal tumors
}

\author{
Emin Karakurt ${ }^{1}$, Mushap Kuru ${ }^{2}$, Serpil Dağ ${ }^{1}$, Enver Beytut ${ }^{1}$, Hilmi Nuhoğlu ${ }^{1}$, Murat Can \\ Demir $^{2}$, Cihan Kaçar ${ }^{2}$, Özhan Karataş ${ }^{3}$ Ayfer Yıldız ${ }^{4}$
}

Research Article

Volume: 4, Issue: 1

April 2020

Pages: $13-20$

\section{Article History}

Received: 09.03.2020

Accepted: 22.04.2020

Available online:

24.04.2020
1.Kafkas University, Veterinary Faculty, Department of Pathology 36100, Kars, Turkey. 2.Kafkas University, Veterinary Faculty, Department of Obstetrics and Gynecology, 36100, Kars, Turkey. 3.Cumhuriyet University, Veterinary Faculty, Department of Pathology, 58140, Sivas, Turkey, 4. Kafkas University, Institute Health Sciences, 36100, Kars, Turkey.

Karakurt E.: ORCID: 0000-0003-2019-3690; Mushap K.: ORCID: 0000-0003-4409-251X, Dağ S.: ORCID: 0000-0001-7667-689X, Beytut E.: ORCID: 0000-0003-3360-2940; Nuhoğlu H.: ORCID: 0000-0003-25302542; Demir M.C.: ORCID: 0000-0002-3803-069X; Kaçar C.: ORCID: 0000-0002-2642-697X; Karataş Ö. ORCID:0000-0002-2778-8059 ; Yıldız A.: ORCID: 0000-0002-6569-5435.

\begin{abstract}
In this study, we aimed to evaluate the proliferative, metastatic and apoptotic capacities of TVT cases, which are in various phases of development, by using immunohistochemical markers. The material of this study consisted of twelve female and six male dogs diagnosed with TVT brought to our department between 2007 and 2020 years. Diff-quick staining was applied to the smear taken from tumoral masses for cytological examinations. Tumoral tissues from dogs were fixed in a $10 \%$ neutral buffered formaldehyde solution. After routine tissue procedures Hematoxylin \& Eosin stain was applied to the sections. Tissue sections were investigated under a light microscope and photographed. Immunohistochemical staining was performed on the tissues using the avidin-biotin immune peroxidase complex method. As a result of macroscopic, cytological and histopathological examinations, TVT positive cases were divided into three according to their developmental stages. While the expression of PCNA, MMP-9, mutant p53 and $\mathrm{BCl}-2$ increased significantly in progressive cases compared to regressive and stable cases, Bax expression increased significantly in regressive cases compared to progressive and stable cases. In conclusion, we thought that the mentioned markers are very useful for understanding the prognosis of TVT, the tumor aggressiveness and the survival of the malignant cells.
\end{abstract}

Keywords: apoptosis, metastasis, proliferation, TVT

DOI: 10.30704/http-www-jivs-net.700692

To cite this article: Karakurt, E., Kuru, M., Dağ, S., Beytut, E., Nuhoğlu, H., Demir, M.C., Kaçar, C., Karataş, Ö., Yıldız, A. (2020). Expression of PCNA, MMP-9, p53, Bax and Bcl-2 in canine transmissible venereal tumors. Journal of Istanbul Veterinary Sciences. 4(1), 13-20, Abbreviated Title: J Ist Vet Sci

\section{Introduction}

Transmissible venereal tumor (TVT) also knowns as mostly found in sexually active, free-circulating, infectious sarcoma, venereal granuloma, young dogs in many regions of the world (Akkoc et. transmissible lymphosarcoma or Sticker tumor, is al., 2017). TVT, which has a higher incidence in the most common genital tumor in dogs (Özyiğit tropical and subtropical regions, mostly affects et. al., 2014; Paramjeet et. al., 2019). This tumor is dogs. In addition, it is known to affect other canids

*Corresponding Author: Emin Karakurt

https://dergipark.org.tr/tr/pub/http-www-jivs-net

E-mail: mehmeteminkarakurt@hotmail.com 
such as foxes, jackals and wolves (Stockmann et. al., 2011a). It has been reported that this tumor is seen with the same frequency in both female and male dogs (Özalp et. al., 2012). The tumor is transmitted from one dog to another by mating (Gupta and Sood, 2012). Although the tumor mostly affects the genital mucosa, it is also occurs in the oral, nasal and conjunctival mucosa (Guvenc et. al., 2002; Coskan et. al. 2011). Although the origin of TVT cells is unclear, it is classified as malignant round cell neoplasia with plasmacytoid or lymphocytic appearance (Flórez et. al., 2017). TVT has its own unique features. The origin of TVT is not shaped by the neoplastic transformation of normal cells. On the contrary, the development and evolutionary process of cells occur as a result of the transmission of clonal cells that pass from infected dogs to healthy dogs (Lima et. al., 2016). TVT cells need cellular disintegration due to their characteristic features before they settle on the mucous membrane. Once the tumor has settled, it can proliferate and spread to other locations in the body and eventually become metastatic. (Alzate et. al., 2019). TVT is highly invasive locally and the rate of metastasis is very low (Oguş and Özmen, 2018). TVT can metastasize to many tissues and organs such as liver, kidney, spleen, eyes, brain, pituitary gland, skin, subcutis, mesenteric lymph nodes and peritoneum (Tiwari et.al., 2016). Differential diagnosis of TVT is made based on cytological and histopathological findings (Oguş and Özmen, 2018). The tumor is evaluated in three phases histopathologically considering its developmental characteristics. These are briefly; proliferative $(P)$, stable $(S)$ and regression (R) phases (Stockmann et. al., 2011b; Setthawongsin et. al., 2019).

In this study, we aimed to evaluate the proliferative, metastatic and apoptotic capacities of TVT cases, which are in various phases of development, by using immunohistochemical markers.

\section{Materials and Methods}

Animals: The material of this study consisted of twelve female and six male dogs diagnosed with TVT brought to our department between 2007 and 2020 years. We divided these 18 animals into 3 phases (progression, stable and regression) including 6 of them.

Cytological Investigations: Diff-quick staining was applied to the smear taken from tumoral masses for cytological examinations.

Histopathological Investigations: Tumoral tissues from dogs were fixed in a $10 \%$ neutral buffered formaldehyde solution. After routine tissue procedures follow-up (dehydrated through graded \%70-100 alcohols, xylol and embedded in paraffin) $5 \mu \mathrm{m}$ thick sections were taken from paraffin blocks. For the examination of histopathological changes in tumoral tissues, Hematoxylin \& Eosin (H\&E) stain was applied to the sections. Tissue sections were investigated under a light microscope (Olympus Bx53) and photographed with Cell $\wedge \mathrm{P}$ Program (Olympus Soft Imaging Solutions $\mathrm{GmbH}, 3,4$ ).

\section{Immunohistochemical Investigations:}

Immunohistochemical staining was applied on the tissues using the avidin-biotin immune peroxidase complex method. For immunohistochemical staining, sections of $4 \mu \mathrm{m}$ thick from paraffin blocks were rehydrated. In order to prevent endogenous peroxidase activity, the sections were treated with $3 \%$ hydrogen peroxide solution for 15 minutes. Then, the microwave method (Citrate Buffer Solution $\mathrm{pH} 6$ for $25 \mathrm{~min}$; boiling for $15 \mathrm{~min}$ and cooling for 10 min at 800 watt) was applied to the sections to reveal the antigenic receptors. In order to prevent nonspecific staining, the sections were incubated for $30 \mathrm{~min}$ with Serum Blocking Solution (Genemed Biotechnologies REF 540003). Following treatment with Phosphate Buffered Salt Solution (PBS) with different antibodies; (PCNA: Santa Cruz, sc-56, Dilution Ratio: 1/100), (MMP-9: Santa Cruz, sc-393859, Dilution Ratio: 1/100), (p53: Novus Bio, SPM590, Dilution Ratio: 1/200), (Bax: Bioss, bs-0127R, Dilution Ratio: 1/200) and (Bcl-2: Bioss, bs-0032R, Dilution Ratio: 1/200) were incubated for overnight. The sections were washed 3 times in PBS solution for 5 minutes, and the biotinylated temperature for 30 minutes. After washing in PBS (3-5 $\mathrm{min}$ ), all sections were incubated with 
Table 1. Statistical comparison of PCNA, MMP-9, p53, Bax and Bcl-2 immune-positive reactions between progression, regression and stable TVT groups

\begin{tabular}{lccccc}
\hline Groups & PCNA & MMP-9 & p53 & Bax & Bcl-2 \\
\cline { 2 - 6 } Progression & $2.83 \pm 0.40^{\mathrm{a}}$ & $2.66 \pm 0.51^{\mathrm{a}}$ & $2.50 \pm 0.54^{\mathrm{a}}$ & $1.33 \pm 0.51^{\mathrm{a}}$ & $2.83 \pm 0.40^{\mathrm{a}}$ \\
Regression & $1.33 \pm 0.51^{\mathrm{b}}$ & $1.16 \pm 0.40^{\mathrm{b}}$ & $1.33 \pm 0.51^{\mathrm{b}}$ & $2.66 \pm 0.51^{\mathrm{b}}$ & $1.33 \pm 0.51^{\mathrm{b}}$ \\
Stable & $2.33 \pm 0.51^{\mathrm{c}}$ & $2.00 \pm 0.63^{\mathrm{c}}$ & $1.83 \pm 0.40^{\mathrm{c}}$ & $2.33 \pm 0.51^{\mathrm{b}}$ & $2.16 \pm 0.40^{\mathrm{c}}$ \\
& $\mathrm{P}<0.05$ & $\mathrm{P}<0.05$ & $\mathrm{P}<0.05$ & $\mathrm{Pp}<0.05$ & $\mathrm{P}<0.05$ \\
\hline
\end{tabular}

$a, b, c$ express the differences between the groups $(p<0.05)$.

(peroxidase-bound Streptavidin-Peroxidase (HRP) Genemed Biotechnologies REF 54-0003) for 30 minutes. A solution of 3,3'-Diaminobenzidine (DAB) (Genemed Biotechnologies REF 10-0048) were used as colour revealing substrate. The sections were stained with Mayer Hematoxylin and coated with immune mount. The sections prepared after the covering were examined under a light microscope (Olympos $\mathrm{B} \times 53$ ) and photographed via the Cell^P program (Olympos Soft Imaging Solutions Gmbh, 3,4).

Statistical analysis: PCNA, MMP-9, p53, Bax and $\mathrm{Bcl}-2$ immune-positive reactions were evaluated under a light microscope negative $(-)$, mild $(+)$, moderate $(++)$ and severe $(+++)$. The data obtained were analyzed with SPSS 20.00 program. The difference between the groups was determined by Kruskal Wallis, one of the nonparametric tests, and the group that created the difference was determined by the Mann Whitney $U$ test $(p<0.05)$.

\section{Results}

Macroscopic results: We determined that tumoral masses have cauliflower appearance. In addition, we detected quite common hemorrhage and ulcerative areas. The tumor was easily crumbly and had a very fragile structure (Figure 1).

Cytological results: In the Diff-quick staining performed on smears taken from tumoral masses, we observed the presence of plasmacytoid tumoral cells with large and vacuolar cytoplasm. It was noteworthy that tumoral cells had a distinct nucleus. Nuclei were eccentrically located. In addition to tumoral cells, the presence of a relatively small number of neutrophil leukocytes was also recorded by us (Figure 2 ).

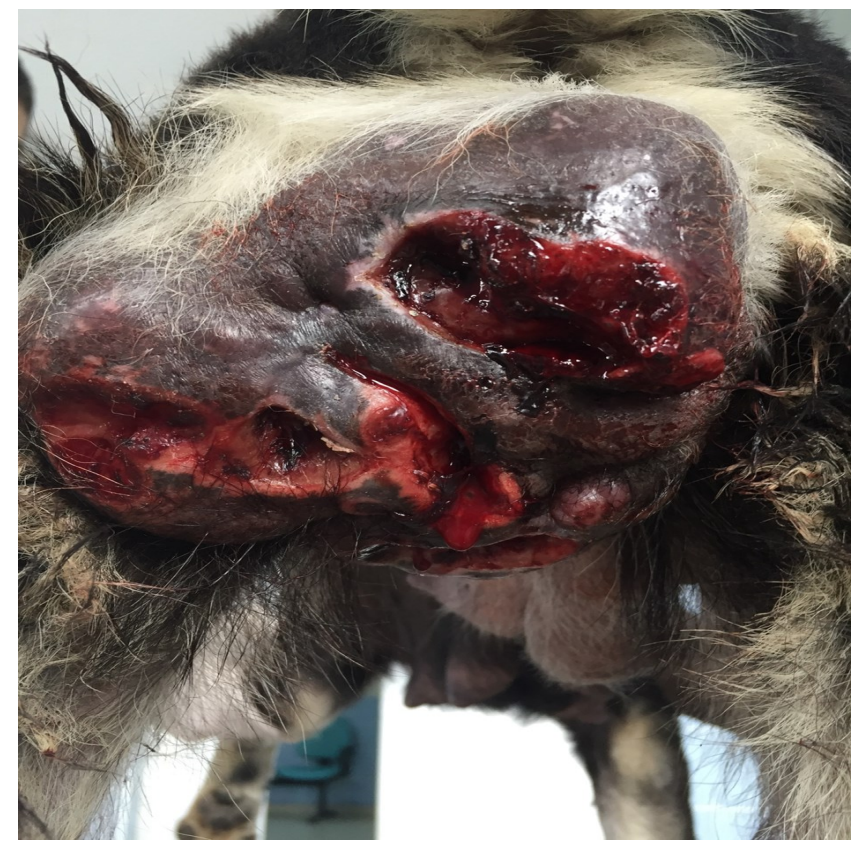

Figure 1. Macroscopic view of tumoral mass, which is quite hemorrhagic.

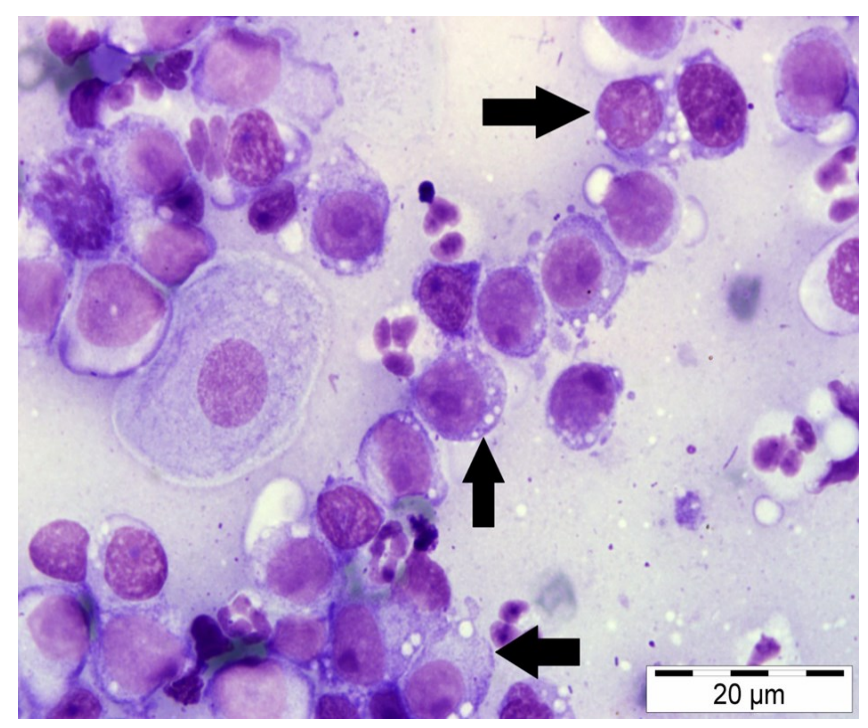

Figure 2. Plasmacytoid tumoral cells with large and vacuolar cytoplasm with an eccentrically located nucleus (arrows), Diff-quick stain, Bar $=20 \mu \mathrm{m}$. 


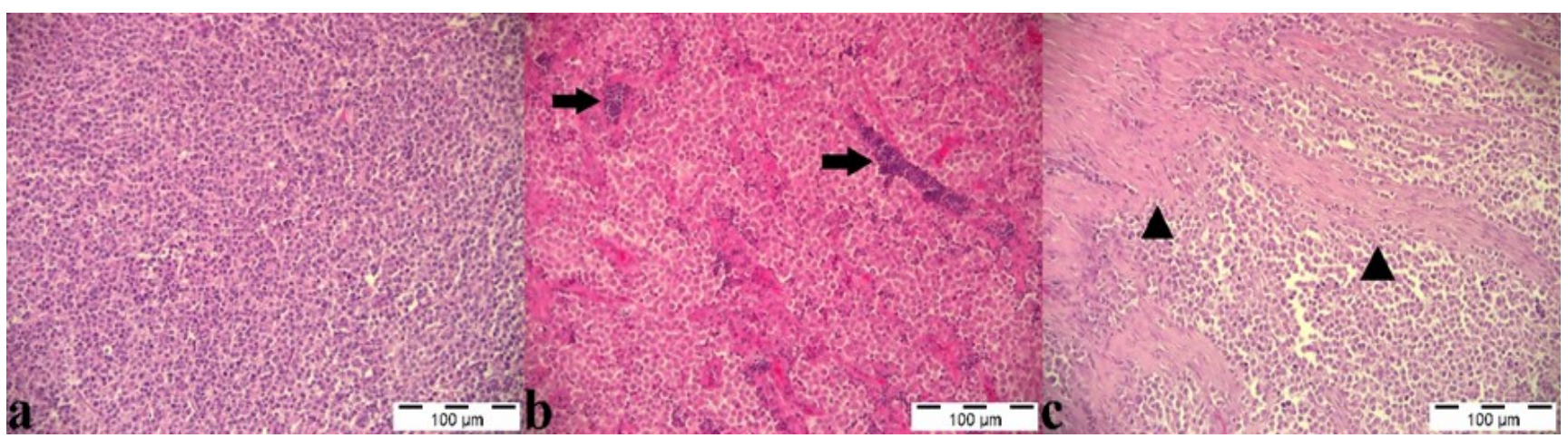

Figure 3. (a) Progression phase TVT case, increase in cellularity and mitotic figures, H\&E, Bar=100 $\mu \mathrm{m}$. (b) Stable phase TVT case, lymphocytes infiltrating the tumoral tissue (arrows), H\&E, Bar=100 $\mu \mathrm{m}$. (c) Regression phase TVT case, decreased cellularity, increased connective tissue (arrowheads), H\&E, Bar=100 $\mu \mathrm{m}$.

secondary antibody (Genemed Biotechnologies REF 54-0003) was applied to them at room

Hematoxylin \& eosin results: In the histopathological examination of tumoral masses; In TVT cases in the progression phase, we found that the tumor cells surrounded by thin fibrous capsules increased significantly and the mitotic figures were abundant (six animals). In addition, we observed areas of intense necrosis and bleeding (Figure 3a). In the stable phase TVT cases, the presence of lymphocytic cells infiltrated into the tumoral foci surrounded by a fibrous capsule attracted our attention (six animals) (Figure $3 \mathrm{~b}$ ). In the regression phase TVT cases, we found that cellularity decreased significantly and fibrous connective tissue increased significantly (six animals) (Figure 3c).

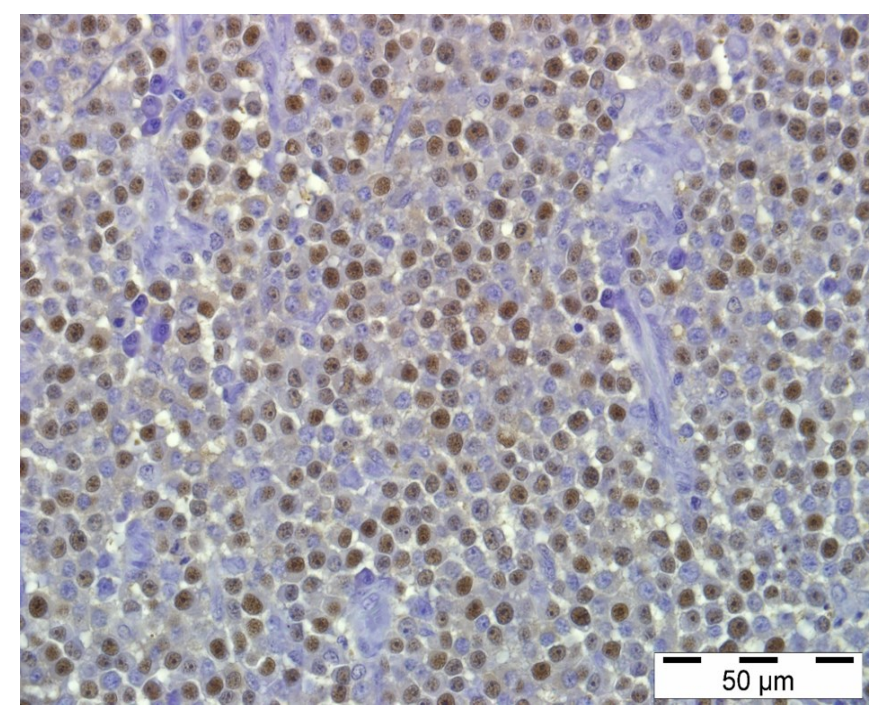

Figure 4. Progression phase TVT case, PCNA immunoreactivity in the nucleus of tumoral cells, IHC, Bar $=50 \mu \mathrm{m}$.
Immunohistochemical results: Statistical comparison of PCNA, MMP-9, p53, Bax and Bcl-2 immune-positive reactions between groups as shown in Table 1. We observed PCNA immunopositive reactions mostly in TVT cases in the progression phase. PCNA positive reaction was especially in the nucleus of the tumoral cells and brown color (Figure 4). MMP-9 immunopositive reaction was also stronger in TVT cases at the phase of progression, similar to PCNA.

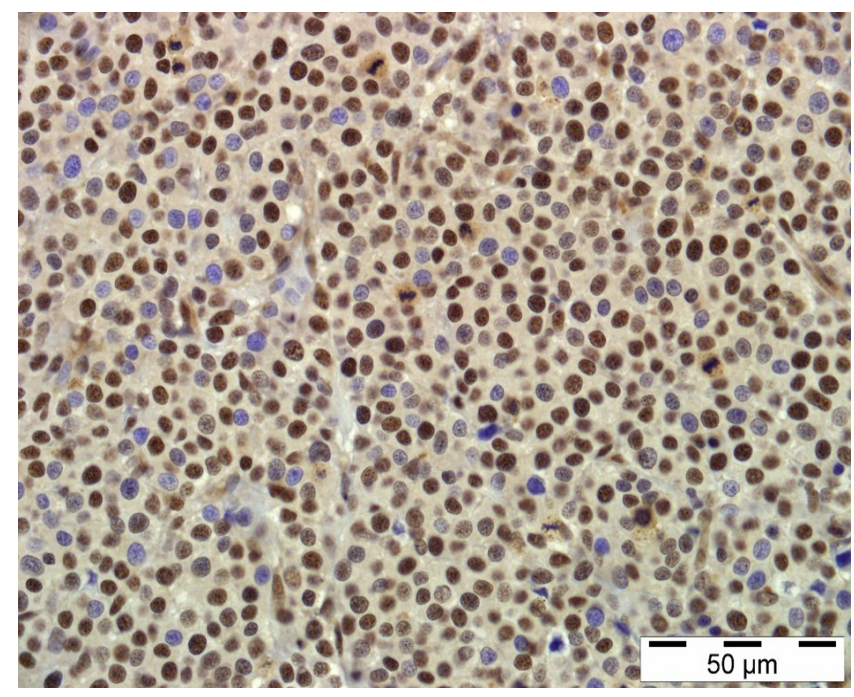

Figure 5. Progression phase TVT case, MMP-9 immune positive reaction in the cytoplasm and nucleus of tumoral cells, IHC, Bar $=50 \mu \mathrm{m}$.

MMP-9 immunoreactivity was seen predominantly in the nucleus of tumoral cells, but less frequently in the cytoplasm (Figure 5). P53 immunoreactivity showed a more pronounced increase, especially in cases of progression TVT. While p53 immunopositive reactions were observed especially in the cytoplasm of tumoral cells, spontaneous positive 


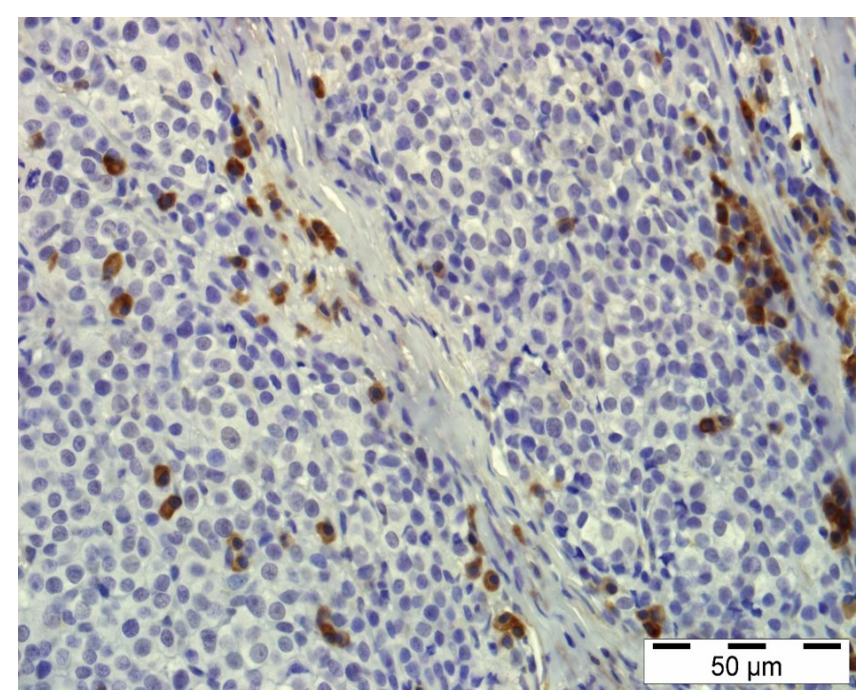

Figure 6. Progression phase TVT case, p53 expression in the cytoplasm and nucleus of tumoral cells, IHC, Bar $=50 \mu \mathrm{m}$.

reactions were observed in the nucleus (Figure 6). The cytoplasmic Bax immunopositive reaction was also stronger in TVT cases at the phase of regression (Figure 7). We observed $\mathrm{Bcl}-2$ immunoreactivity especially in the cytoplasm and membrane of tumoral cells. The expression of $\mathrm{Bcl}-2$ was higher as to Bax expression in progression cases than regression cases (Figure 8).

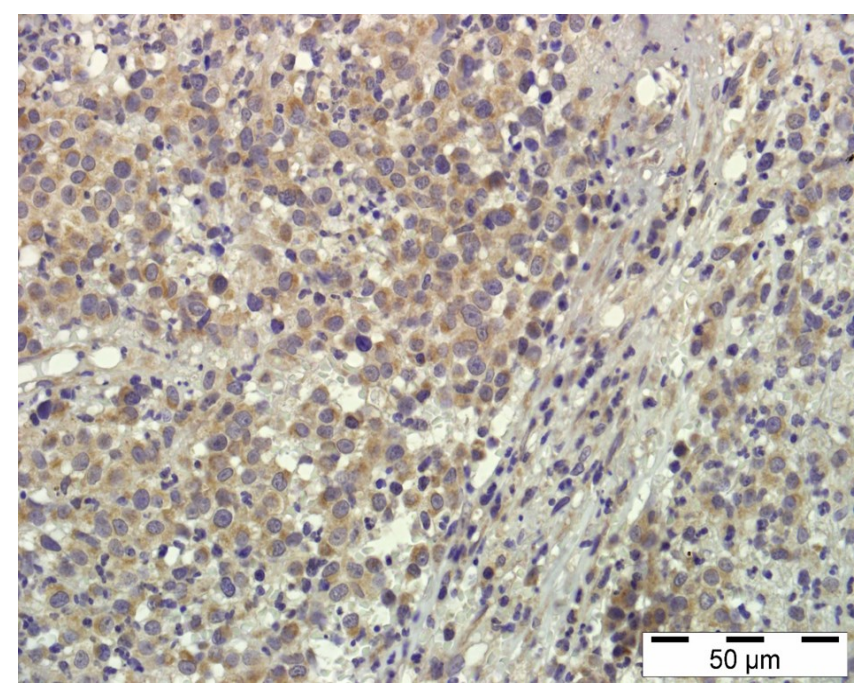

Figure 7. Regression phase TVT case, Bax immunoreactivity in the cytoplasm of tumoral cells, IHC, Bar $=50 \mu \mathrm{m}$.

\section{Discussion and Conclusion}

Detection of tumor cell division rate is an important parameter in determining tumor aggressiveness and prognosis (Tiwari et al., 2016). Proliferating cell nuclear antigen (PCNA), which is used to calculate the proliferation index in animal neoplasms, is associated with DNA replication and repair (Gupta and Sood, 2012). Although it is present at all of the cell cycle stages, it reaches the maximum level in the $S$ phase (Madewell, 2001). The increase in PCNA expression is valuable in terms of high proliferation rate and degree of aggressiveness (Paramjeet et al., 2019). In our study, we evaluated a highly reliable marker PCNA expression in order to compare the stages of development of TVT cases in terms of cell proliferation (Chu et al., 2001). Similar to previous studies (Chu et al., 2001; Tiwari et al., 2016) we detected PCNA expression at a

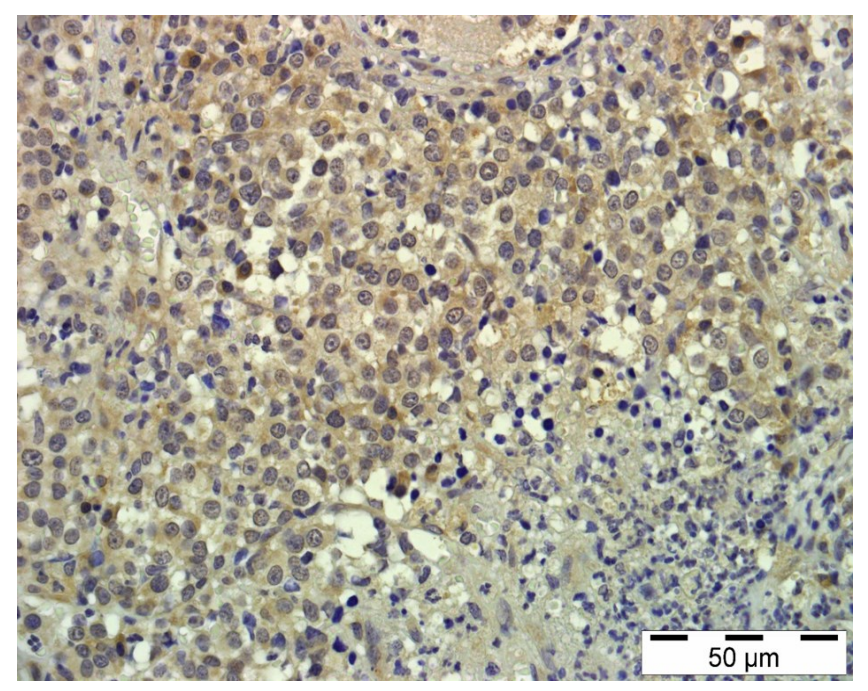

Figure 8. Progression phase TVT case, Bcl-2 immunoreactivity in the cytoplasm and membrane of tumoral cells, IHC, Bar $=50 \mu \mathrm{m}$.

statistically higher rate in TVT cases at the progression stage compared to regression and stable stage cases. The PCNA reaction was in the nucleus of the tumoral cells and moderate to severe in accordance with the literature data (Gupta and Sood, 2012; Lokesh et al., 2014; Tiwari et al., 2016; Paramjeet et al., 2019). According to the results of our study, we thought that PCNA is a very reliable marker in determining tumor aggression and prognosis in TVT cases.

The most vital task of the extracellular matrix (ECM) is to protect the tissues with their specific and mechanical properties (Oguş and Özmen, 2018). Matrix metalloproteinases (MMPs) play a role in the degradation of ECM proteins. 
Elimination of the ECM proteins that surround the tumor cells is an important step for metastasis. (Akkoc et. al., 2017). Increased concentrations of MMPs have been associated with invasion, metastasis and poor prognosis in many malignancies of humans (Loukopoulos et al., 2003; Aresu et al., 2011). MMP-2 and MMP-9 are the most studied proteases in cancer biology (Akkoc et al., 2017). Although TVT has a very low capacity to metastasize, it can metastasize to many tissues and organs such as liver, kidney, spleen, eyes, brain, pituitary gland, skin, subcutis, mesenteric lymph nodes and peritoneum (Tiwari et al., 2016). In our study, we evaluated MMP -9 expressions immunohistochemically to compare the metastatic capacities of different stages of the tumor. In accordance with previous studies, all TVT cases responded positively with MMP-9 (Akkoc et al. 2017). Unlike this study, MMP-9 expression was observed especially in the nucleus of tumoral cells, while cytoplasmic reactions were milder than nuclear reactions (Akkoc et al. 2017). In addition, we detected MMP-9 immunoreactivity especially in cases of progressive stage. Unfortunately, we do not have sufficient information on whether these cases have metastasized because of insufficient information from the animal owners after the surgical operations. However, in cases where MMP-9 expressions are high, we believe that especially immune system suppressed animals can metastasize to distant tissues. (Özalp et al., 2012).

When any DNA damage occurs in normal cells, an increase in the p53 gene is formed, and the cell cycle is blocked at the G1 stage and the damaged cell is given time for repair. If the damage is quite severe, apoptosis, a programmed cell death rather than repair, is activated (Moro et al., 2010). p53, also known as the guardian of the genome, plays an important role in regulating the cell cycle and maintaining the integrity of the genome (Santos et al., 2010). Mutations in the p53 gene are quite common in different types of tumors, and as a result of these mutations, the gene cannot perform its normal functions. Thus, the DNA damage in the cell cannot be repaired or if the damage is very severe, the apoptosis mechanism cannot be activated. (Gerardi et al., 2014). The p53 protein is quickly eliminated as it has a short half-life of 20 minutes. The half-life of the mutant p53 protein is several hours, which allows it to be detected by immunohistochemical methods (Tiwari et al., 2014).
In our study, we preferred the mutant p53 gene compared to the normal p53 gene due to its long half -life. In accordance with previous literature data, we detected p53 immunoreactivity in the cytoplasm and nucleus of tumoral cells (Coskan et al., 2011; Gupta and Sood, 2012; Gerardi et al., 2014). Stockmann et al. $2011 \mathrm{~b}$ reported that they encountered a p53 positive reaction at all stages, regardless of the stage of development of the tumor. Moro et al. 2010 detected more p53 immunopositive cells in the regression phase in TVT. In our study, we determined more mutant p53 gene expressions especially in progressive TVT cases similar to previous studies (Santos et al., 2008; Gerardi et al., 2014). In the light of these results, we thought that mutations in the p53 gene block apoptosis and trigger uncontrolled cell proliferation (Santos et al. 2008; Moro et al., 2010). It supports our opinion that especially the cases in the progression stage show more severe mutant p53 gene expression. We have interpreted that mutations in the p53 gene in TVT of dogs can affect the development and aggressiveness of this tumor.

The intrinsic pathway is regulated by the $B$ cell lymphoma 2 ( $\mathrm{Bcl}-2$ ) family. The protein $\mathrm{X}$ associated with $\mathrm{BCL2}(\mathrm{Bax})$ is a proapoptotic protein that triggers mitochondrial membrane permeability in response to apoptotic stimuli. In contrast, $\mathrm{Bcl}-2$ is an anti-apoptotic protein that protects cell death (Alzate et al., 2019). In the antiapoptotic effect of Bcl-2, it is important to stabilize the mitochondrial membrane and prevent the release of cytochrome-c (Lokesh et al.; 2014). Therefore, the balance between these two proteins is very important (Setthawongsin et al., 2019). Over-expression of Bcl-2 is seriously associated with the survival of malignant tumor cells, especially their aggressiveness and poor prognosis (Özyiğit et al., 2014). Also, overexpression of Bcl-2 may be related to the mutant p53 gene (Stockmann et al. 2011a). In our study, similar to this data, mutant p53 and Bcl-2 expressions were highest in progressive TVT cases. Stockmann et al. 2011b reported that $\mathrm{Bcl}-2$ overexpression is independent of TVT development phases. Lokesh et al. 2014 reported that they could not detect the $\mathrm{Bcl}-2$ reaction in TVT cases. Similar to previous studies (Özyiğit et al., 2014; Setthawongsin et al., 2019), we observed that $\mathrm{BCl}-2$ expression was more severe in progressive TVT cases and Bax expression was more severe in regressive TVT cases. 
In conclusion, in our study, we evaluated the proliferation, apoptosis and metastasis properties of TVT by various markers such as these markers in detail in cases where we divided them into three as progression, stable and regression phases according to their histopathological features and compared the PCNA, MMP-9, p53, Bax and Bcl-2. We evaluated

cases statistically with each other. As a result of the evaluations, we thought that the mentioned markers are very useful for understanding the prognosis of TVT, the tumor behavior and the survival of the cells. From this aspect, we believed that the data obtained from this study will contribute to the literature.

\section{References}

Akkoc, A., Nak, D., Demirer, A., \& Şimşek, G. (2017). Immunocharacterization of matrix metalloproteinase-2 and matrix metalloproteinase- 9 in canine transmissible venereal tumors. Biotechnic \& Histochemistry, 92(2), 100-106.

Alzate, J. M., Montoya-Florez, L. M., Pérez, J.E., Rocha, N. S., \& Pedraza-Ordonez, F. J. (2019). The role of the multi-drug resistance $1, p 53, b$ cell lymphoma 2 , and $\mathrm{bcl} 2$-associated $X$ genes in the biologic behavior and chemotherapeutic resistance of canine transmissible venereal tumors. Veterinary Clinical Pathology, 48(4), 730 $-739$.

Aresu, L., Giantin, M., Morello, E., Vascellari, M., Castagnaro, M., Lopparelli, R., Zancanella, V., Granato, A., Garbisa, S., Aricò, A., Bradaschia, A., Mutinelli, F., \& Dacasto, M. (2011). Matrix metalloproteinases and their inhibitors in canine mammary tumors. BMC Veterinary Research, 7, 33.

Chu, R. M., Lin, C. Y., Liu, C. C., Yang, S. Y., Hsiao, Y. W., Hung, S. W., Pao, H. N., \& Liao, K. W. (2001). Proliferation characteristics of canine transmissible venereal tumor. Anticancer Research. 21(6A), 4017-4024.

Coskan, A. S., Alcigir, M. E., \& Atalay Vural, S. (2011). Pathomorphological and immunohistochemical findings in a case of extragenital canine transmissible venereal tumour. Bulgarian Journal of Veterinary Medicine, 14(4), 252-256.

Flórez, M. M., Fêo, H. B., da Silva, G. N., Yamatogi, R. S., Aguiar, A. J., Araújo Jr, J. P., \& Rocha, N. S. (2017). Cell cycle kinetics, apoptosis rates and gene expressions of MDR-1, TP53, BCL-2 and $B A X$ in transmissible venereal tumour cells and their association with therapy response. Veterinary and Comparative Oncology, 15(3), 793-807.

Gerardi, D. G., Tinucci-Costa, M. Silveira, A. C. T., \& Moro, J. V. (2014). Expression of P-glycoprotein, multidrug resistance-associated protein, glutathione-S-transferase pi and p53 in canine transmissible venereal tumor. Pesquisa Veterinária Brasileira, 34(1), 71-78.

Gupta, K. \& Sood, N. K. (2012). Pathological and immunohistochemical studies on rare cases of primary extra-genital transmissible venereal tumours in the mammary gland. Veterinarni Medicina, 57(4), 198-206.

Guvenc, T., Haligur, M., Orman, M. N., \& Haziroglu, R. (2002). Mitosis and apoptosis in canine cutaneous histiocytoma and transmissible venereal tumour. Acta Veterinaria Hungarica, 50(3), 315-321.

Lima, C. R. O., Faleiro, M. B. R., Rabelo, R. E., Vulcani, V. A. S., Rubini, M. R., Torres, F. A. G., \& Moura, V. M. B. D. (2016). Insertion of the LINE1 element in the C-MYC gene and immunoreactivity of C-MYC, p53, p21 and p27 proteins in different morphological patterns of the canine TVT. Arquivo Brasileiro de Medicina Veterinária e Zootecnia, 68(3), 658-666.

Lokesh, J. V., Kurade, N. P., Shivakumar, M. U., Sharma, A. K., \& Maiti, S. K. (2014). Evaluation of BCL-2 and PCNA expression and mitotic index in spontaneous canine tumors. Advances in Animal and Veterinary Sciences, 2(1), 63-66.

Loukopoulos, P., Mungall, B. A., Straw, R. C., Thornton, J. R., \& Robinson, W. F. (2003). Matrix metalloproteinase-2 and -9 involvement in canine tumors. Veterinary Pathology, 40(4), 382- 
Madewell, B. R. (2001). Cellular proliferation in tumors: a review of methods, interpretation, and clinical applications. Journal of Veterinary Internal Medicine, 15(4), 334-340.

Moro, J. V., Tinucci-Costa, M., Silveira, A. C. T., Gerardi, D. G., \& Alessi, A. C. (2010). Reactivity of p53 protein in canine transmissible venereal tumor. Arquivo Brasileiro de Medicina Veterinária e Zootecnia, 62(2), 318-323.

Oguş, E. \& Özmen, Ö. (2018). Immunohistochemical determination of the matrix metalloproteinase- 2 and -7 expression in transmissible venereal tumor in dogs. Mehmet Akif Ersoy Üniversitesi Veteriner Fakültesi Dergisi, 3(2), 106-110.

Özalp, G. R., Zik, B., Bastan, A., Peker, S., ÖzdemirSalci, E. S., Bastan, I., Darbaz, I., Salar, S., \& Karakas, K. (2012). Vincristine modulates the expression of Ki67 and apoptosis in naturally occurring canine transmissible venereal tumor (TVT). Biotechnic \& Histochemistry, 87(5), 325330.

Özyiğit, M. Ö., Nak, D, Akşit, H., İnan Öztürkoğlu, S. Şimşek, G. Uzabacı, E., Nak. Y, \& Seyrek, K. (2014). The effects of vincristine sulfate on expression of galectin-3, $\mathrm{BCl}-2$, and carbohydrate structures specific for EEL, GSL-1, and RCA-1 lectins in bitches with naturally occuring canine transmissible venereal tumor. Turkish Journal of Veterinary and Animal Sciences, 38, 331-338.

Paramjeet, Jangir, B. L., Lather, D., Saharan, S., \& Jakhar, K. K. (2019). Pathomorphological and immunohistochemical studies on transmissible venereal tumours in dogs. Haryana Veterinarian, 58(1), 82-85.

Santos, F. G. A., Vasconcelos, A. C., Nunes, J. E. S., Cassali, G. D., Paixão, T. A., Martins, A. S., Silva,
S. S., Martins, R. F., \& Moro, L. (2008). Apoptosis in the transplanted canine transmissible venereal tumor during growth and regression phases. Arquivo Brasileiro de Medicina Veterinária e Zootecnia,60(3), 607-612.

Setthawongsin, C., Teewasutrakul, P., Tangkawattana, S., Techangamsuwan, S., \& Rungsipipat, A. (2019). Conventional-vincristine sulfate vs. modified protocol of vincristine sulfate and l-asparaginase in canine transmissible venereal tumor. Frontiers in Veterinary Science, 6, 300.

Stockmann, D., Ferrari, H. F., Andrade, A. L., Rodrigo, A. L., Cardoso, T. C., \& Luvizotto, M. C. (2011a). Canine Transmissible Venereal Tumors: Aspects Related to Programmed Cell Death. Brazilian Journal of Veterinary Pathology, 4(1), 67-75.

Stockmann, D., Ferrari, H. F., Andrade, A. L., Cardoso, T. C., \& Luvizotto, M. C. (2011b). Detection of the tumour suppressor gene TP53 and expression of $\mathrm{p} 53, \mathrm{Bcl}-2$ and $\mathrm{p} 63$ proteins in canine transmissible venereal tumour. Veterinary and Comparative Oncology, 9(4), 251 -259 .

Tiwari, K. P., Bhaiyat, M. I., Chikweto, A., Inga, A., Sharma, R. N., \& Pawaiya, R. V. S. (2014). Immunohistochemical detection of p53 tumor suppressor protein in round cell tumors of dogs in Grenada, West Indies. Advances in Animal and Veterinary Sciences, 2(3S), 23-27.

Tiwari, K. P., Bhaiyat, M. I., Chikweto, A., Sharma, R. N., Younger, C. H., \& Pawaiya, R. V. S. (2016). Expression pattern of proliferating cell nuclear antigen (PCNA) in round cell tumors of dogs from Grenada, West Indies. Indian Journal of Veterinary Pathology, 40(2), 144-147. 